\title{
Euphorbia bupleuroides Desf. latex as biopesticide against the red flour beetle (Tribolium castaneum [Herbst, 1797]) and khapra beetle (Trogo- derma granarium Everts, 1898)
}

\author{
Imene BRIK ${ }^{1,2}$, Naama FRAH ${ }^{1}$
}

Received January 05, 2021; accepted March 26, 2021.

Delo je prispelo 5. januarja 2021, sprejeto 26. marca 2021.

Euphorbia bupleuroides Desf. latex as biopesticide against the red flour beetle (Tribolium castaneum [Herbst, 1797]) and khapra beetle (Trogoderma granarium Everts, 1898)

Abstract: Laboratory evaluation of Euphorbia bupleuroides latex as biopesticide against the red flour beetle (Tribolium castaneum) and khapra beetle (Trogoderma granarium) were evaluated at ambient temperature. The insecticidal activity of latex was determined by direct contact application. Different concentrations were prepared by dilution of 2.5, 5.0, 7.0 and $10.0 \mu \mathrm{l}$ of latex into $0.1 \mathrm{ml}$ acetone. $1 \mu \mathrm{l}$ was pumped regularly in the thorax of different insects. The latex of E. bupleuroides showed insecticidal activity against $T$. granarium and T. castaneum. High levels of mortality were associated with the increase in the concentration and time of exposure as well. T. granarium adults are generally more prone to latex insecticidal effects than T. castaneum adults. After 6 days of exposure to E. bupleuroides latex, the $\mathrm{LC}_{50}$ recorded was $14.12 \mu \mathrm{l}$ for $T$. granarium adults, and $14.7 \mu \mathrm{l}$ for $T$. castaneum. $\mathrm{LC}_{90}$ numbers, on the other hand, were $38.8 \mu \mathrm{l}$ for the former, and $51.44 \mu \mathrm{l}$ for the latter.

Key words: Euphorbia bupleuroides; biopesticide; latex; Tribolium castaneum; Trogoderma granarium; mortality
Mleček prerastolikega mlečka (Euphorbia bupleuroides Desf.) kot bioinsekticid za zatiranje riževega mokarja (Tribolium castaneum [Herbst, 1797]) in indijskega žitnika (Trogoderma granarium Everts, 1898)

Izvleček: Laboratorijsko vrednotenje mlečka iz prerastolikega mlečka (Euphorbia bupleuroides Desf.) kot bioinsekticida za zatiranje riževega mokarja (Tribolium castaneum (Herbst, 1797)) in indijskega žitnika (Trogoderma granarium Everts,1898) je bilo izvedeno pri sobni temperaturi. Insekticidna aktivnost mlečka je bila določena $\mathrm{z}$ neposrednim nanosom. Različne koncentracije so bile pripravljene $\mathrm{z}$ razredčenjem 2,5; 5,$0 ; 7,0$ in $10,0 \mu \mathrm{l}$ mlečka $\mathrm{v} 0,1 \mathrm{ml}$ acetona. $1 \mu \mathrm{l}$ raztopine je bil previdno vbrizgan $\mathrm{v}$ oprsje hroščev. Mleček prerastolikega mlečka je izkazal insekticidno delovanje na oba preučevana hrošča. Velika smrtnost hroščev je bila povezana s povečanimi koncentracijami in daljšim časom izpostavitve. Odrasli osebki indijskega žitnika so bili na splošno bolj dovzetni za strupeni učinek mlečka kot odrasli osebki riževega mokarja. Po šestih dnevih izpostavitve mlečku je bila $\mathrm{LC}_{50}$ za indijski žitnik 14,12 $\mu \mathrm{l}$ in $14,7 \mu \mathrm{l}$ za riževega mokarja. $\mathrm{LC}_{90}$ vrednost je bila za prvega $38,8 \mu \mathrm{l}$ in $51,44 \mu \mathrm{l}$ za drugega.

Ključne besede: Euphorbia bupleuroides; bioinsekticid; mleček; Tribolium castaneum; Trogoderma granarium; smrtnost

1 Laboratory for Improving Agricultural Productions and Protection of resources in arid zones, Department of Agronomy, Institute of Veterinary and Agricultural Sciences, University of Batna 1, Hadj Lakhdar, Algeria

2 Corresponding Author, e-mail: Imenebio5@gmail.com. 


\section{INTRODUCTION}

Pest insects can potentially be carriers of pathogens, and are a substantial contributing source of allergens. That is because of their large cosmopolitan population and high numbers at homes and other buildings (Chang and Anh, 2002). Interest in developing safer alternatives to potentially replace toxic chemicals in pest control is increasingly growing. Bioactive substances and plant insecticides serve different functions in pest control: act as repellents, impact oviposition or feeding, disrupt development, or serve as pest insecticides (Isman, 2017, as cited in Bohinc et al. (2020).

The use of plant extracts is one of the most desirable pest control methods (Salvadores et al., 2007). Plants secondary metabolites are recognized for their crucial role in pest control due to the selective, biodegradable, nontoxic nature of their products, as well as possessing fewer harmful side-effects on non-targeted organisms and the environment (Wink, 1993). Approximately 250,000 species of plants on earth have been labelled as possessing compounds with insecticidal properties (Rafael, 2001).

Euphorbiaceae family is one of the largest and most diverse family in the plant kingdom; comprising of 7800 species in 300 genera (Webster, 1994). Diterpenoids and triterpenoids secondary metabolites are substantially present in Euphorbia species (Giner et al., 2000). They are endowed with striking biological anti-cancer qualities; for instance, they can serve antitumor purposes (Tanaka et al., 2000), anti-proliferative (Cateni et al., 2010), antioxidant and cytotoxic (Aslanturk et al., 2013), and modulators of multidrug resistance (Vasas et al., 2012).

Euphorbia bupleuroides Desf. is labelled as an herbaceous plant, characterized by plain and simple leaves. It is commonly found in mountain rock areas (Quezel and Santa, 1963), and is utilized in Algeria as an endemic medicinal plant in traditional medicine with varied uses ranging from the extirpation of thorns to the treatment of warts, as well as the use of the decoction of roots for antiinflammatory purposes. Furthermore, two of the major chemical compounds of E. bupleuroides are diterpenoids and triterpenoids (Aichour et al., 2014). They are the most relevant in the insecticidal nature of $E$. bupleuroides and similar plants (Singh, 2012; Vimal and Das, 2014).

This study is conducted to assess the toxicity of Euphorbia bupleuroides latex against grain pests, red flour beetle (Tribolium castaneum [Herbst]) and khapra beetle (Trogoderma granarium Everts).

\section{MATERIAL AND METHODS}

\subsection{PLANT MATERIAL}

In April 2018, samples of Euphorbia bupleuroides were collected from their natural habitat of mountain rock areas around Tazoult, east of the city of Batna in the North East of Algeria ( $35^{\circ} 28^{\prime} 54^{\prime \prime} \mathrm{N}, 6^{\circ} 15^{\prime} 39^{\prime \prime} \mathrm{E}$ ).

\subsection{LATEX PREPARATION}

The stems of the collected samples of Euphorbia bupleuroides were cut using a knife, allowing the latex to come out into a container. Latex was then collected in beakers, which were then corked tightly to prevent both evaporation and solidification. They were, after that, labeled and preserved in a refrigerator to maintain freshness. The whole procedure took approximately three days overall.

\subsection{INSECTS}

Cultures of the red flour beetle (Tribolium castaneum) and khapra beetle (Trogoderma granarium) were maintained at $27{ }^{\circ} \mathrm{C}$ and $65 \%$ relative humidity (RH) on a wheat flour of a growth culture room in the dark. Adult insects, 1-7 days old, were used for bioassay.

\subsection{BIOASSAY METHODS}

\subsubsection{Insecticidal Activity}

The insecticidal activity of latex was determined by direct contact application. Different concentrations were prepared by dilution of $2.5,5.0,7.0$, and $10.0 \mu \mathrm{l}$ of latex into $0.1 \mathrm{ml}$ acetone. For each preparation, $1 \mu \mathrm{l}$ was pumped regularly in the thorax of different insects; 10 adult insects were enclosed in a Petri dish. Controls were treated similarly but exposed only to acetone. Each concentration and control were replicated four times. Mortality percentage was determined at 2, 4 and 6-days following treatment. Upon the observation of no leg or antennal movements were, insects were considered dead. The percentage of insect mortality was calculated using Abbott's correction formula for natural mortality in untreated controls (Abdel-Sattar et al.,2010). 


\subsection{STATISTICAL ANALYSIS}

Probit analysis of concentration-mortality data was conducted to estimate the $\mathrm{LC}_{50}, \mathrm{LC}_{90}$ values, their $95 \%$ confidence intervals and related parameters (Finney, 1971). Probit analysis was fitted using the "LC_probit" function in the "ecotox" package in R (Robertson et al., 2007).

\section{RESULTS AND DISCUSSION}

The insecticidal activity of E. bupleuroides latex was tested against T. granarium and T. castaneum (Table 1). Data on the accumulative mortality of the two stored products insect species along 6 days of exposure to latex revealed that E. bupleuroides latex was significantly toxic for both species, though at different concentrations, all slope regressions were qualified significant $(p<0.05)$ (Table 1).

The mortality rates of $T$. castaneum are summarized in Figure 1. At a concentration of $5 \mu \mathrm{l}$, mortality rates remained negligible from day 2 up to day 6 . However, after 6 days, mortality rates increased from 5 to $90 \%$. The higher the concentration, the less time is required to achieve high levels of toxicity. At $7.5 \mu \mathrm{l}$ and $10 \mu 1,10$ and $42.5 \%$ mortality rates are observable after 2 days, 7.5 and $20 \%$ after 4 days, and 57.5 to $90 \%$ after 6 days. The highest concentration $(10 \mu \mathrm{l})$ caused $42.5 \%$ a mortality rate just after 2 days of exposure (Figure 1).

The results on Figure 2 demonstrate that the mortality rate of $T$. granarium adults varied with concentrations and time. In fact, after 6 days, the recorded mortality rate was $15,22.5$, and $40 \%$ using 5.0, 7.5, and $10.0 \mu \mathrm{l}$ concentrations respectively.

Lethal concentrations of latex were calculated after 2, 4, and 6 days of exposure for both species. Results showed that $T$. granarium adults are generally more sensitive to latex insecticidal effects than T. castaneum adults (Table 1). Evidently, after 6 days of exposure to E. bupleuroides latex, the $\mathrm{LC}_{50}$ recorded was $14.12 \mu \mathrm{l}$ for T. granarium adults, and $14.7 \mu 1$ for T. castaneum. LC $_{90}$ numbers, on the other hand, were $38.8 \mu$ for the former, and $51.44 \mu \mathrm{l}$ for the latter (Table 1).

Mortality rates increased with rising concentration levels of E. bupleuroides latex. Additionally, mortality rates of T. castaneum and T. granarium differed in accordance with the different concentration levels of $E$. $b u$ pleuroides latex.

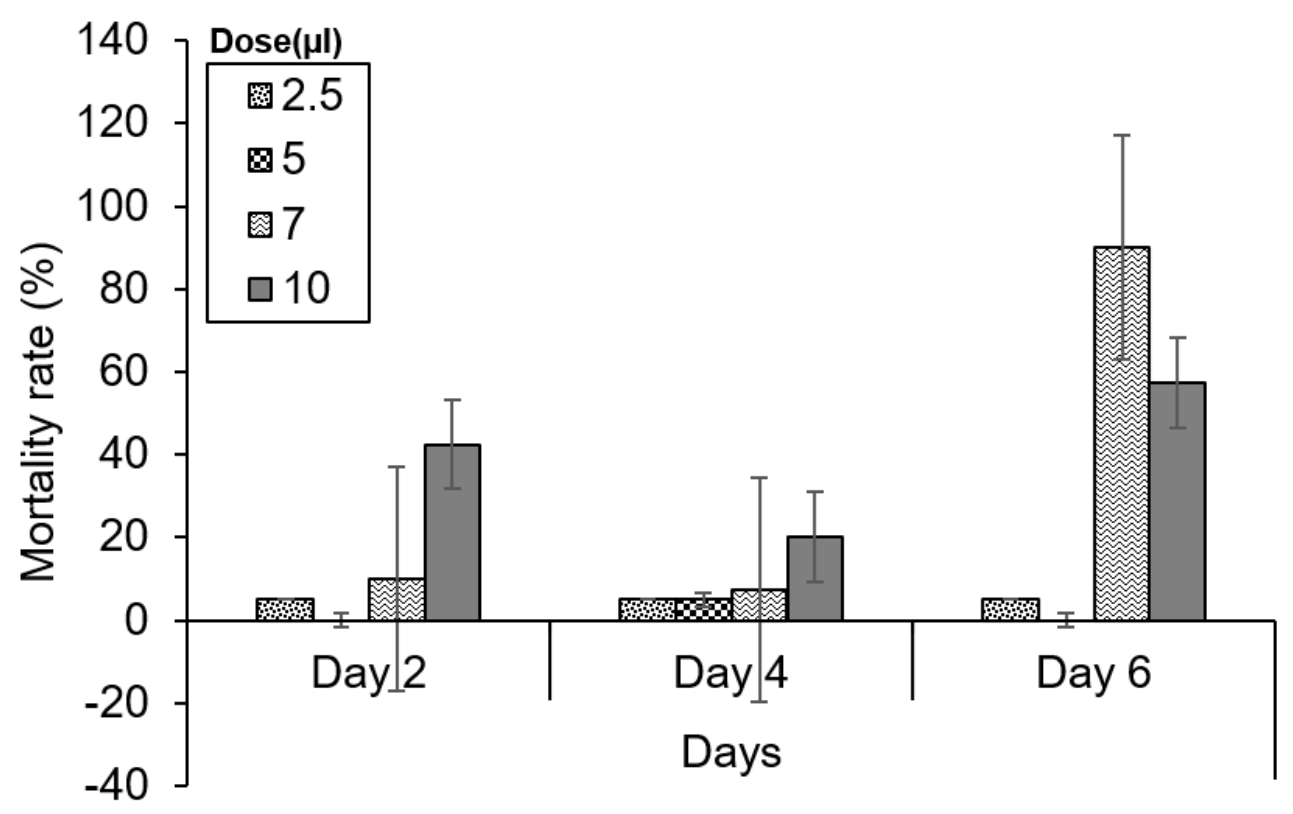

Figure 1: Mortality rates in T. castaneum treated with different concentrations of latex. 


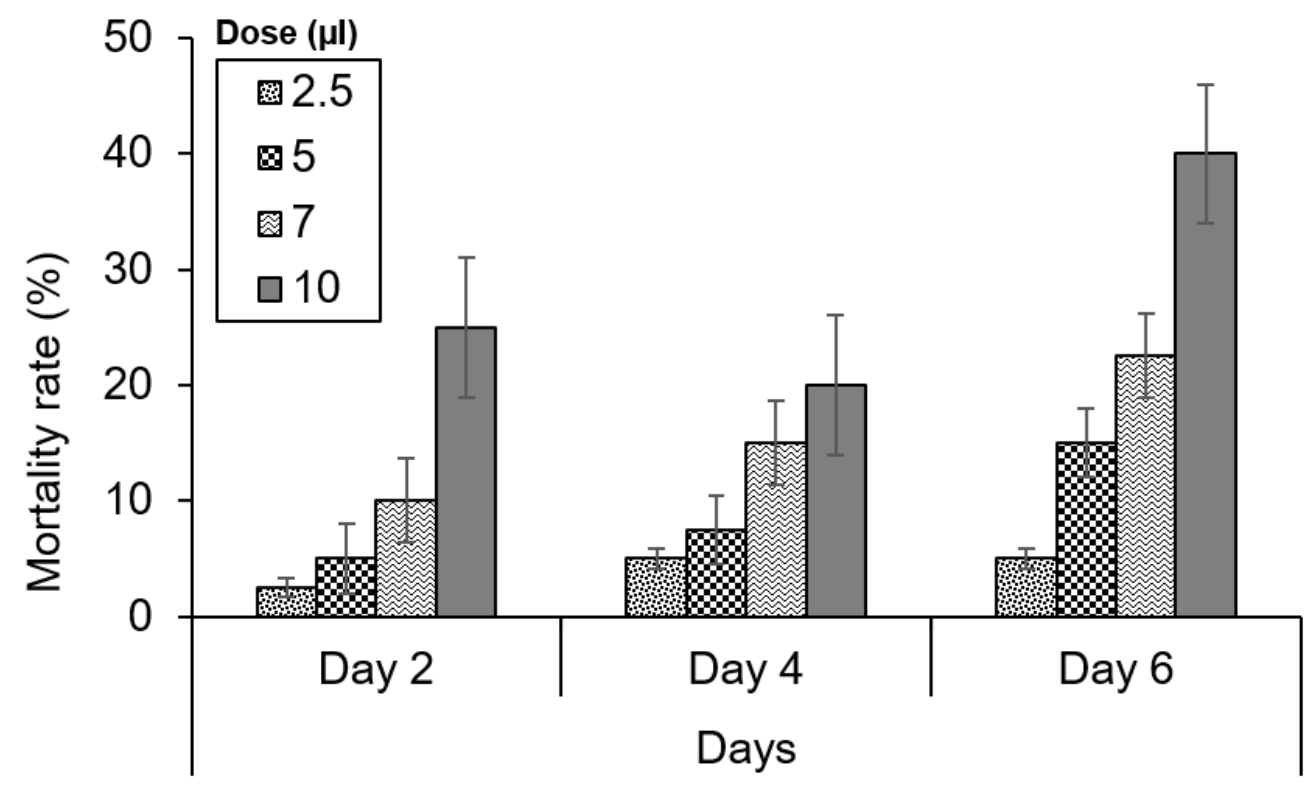

Figure 2: Mortality rates in T. granarium treated with different concentrations of latex.

Table 1: Latex toxicity on T. castaneum and T. granarium adults $\left(\mathrm{LC}_{50}\right.$ and $\left.\mathrm{LC}_{90}\right)$ after 2, 4, and 6 days.

\begin{tabular}{cccccccc}
\hline Species & $\begin{array}{c}\text { Assay time } \\
(\text { days })\end{array}$ & $\mathrm{LC}_{50}(\mu \mathrm{l})$ & $95 \% \mathrm{LCL}-\mathrm{UCL}$ & $\mathrm{LC}_{90}(\mu \mathrm{l})$ & 95\% LCL $-\mathrm{UCL}$ & Slope \pm SE & $\mathrm{P}$ \\
\hline \multirow{2}{*}{$\begin{array}{c}\text { Tribolium } \\
\text { castaneum }\end{array}$} & 2 & 14.7 & $9.76-9.81 \mathrm{E}+3$ & 38.8 & $17.02-1.93 \mathrm{E}+8$ & $3.04 \pm 0.860$ & 0.0004 \\
& 4 & 56.03 & $17.98-5.23 \mathrm{E}-42$ & 482.05 & $53.42-3.77 \mathrm{E}-84$ & $1.37 \pm 0.715$ & 0.049 \\
\cline { 2 - 8 } & 2 & 14.7 & $9.76-9.81 \mathrm{E}+3$ & 38.8 & $17.02-1.93 \mathrm{E}+8$ & $3.04 \pm 0.860$ & 0.0004 \\
\hline $\begin{array}{c}\text { Trogoderma } \\
\text { granarium }\end{array}$ & 4 & 40.74 & $16.10-3.613 \mathrm{E}+09$ & 320.08 & $48.72-2.040 \mathrm{E}+19$ & $1.43 \pm 0.663$ & 0.031 \\
& 6 & 14.12 & $9.44-105.5$ & 51.44 & $21.14-9780.8$ & $2.28 \pm 0.625$ & 0.0002 \\
\hline
\end{tabular}

\section{DISCUSSION}

Different plants belonging to the Euphorbiaceae family have been studied all over the world for their toxic constituents. For instance, according to Govindarajan et al. (2008), Leaf extract of Acalypha indica L. exhibits larvicidal and ovicidal activities against malaria vector - Anopheles stephensi Liston, 1901. Acalypha alnifolia Klein ex Willd. extracted leaves demonstrated, in similar fashion to Acalypha indica L., larvicidal properties, but differed in having pupicidal effects-rather than ovicidal-against the same species (Murugan et al., 2011). De Silva et al. (2008) studied the insecticidal properties of Euphorbia antiquorum L. latex againt rice insect pests, whilst Euphorbia fischeriana Steud. had anti-feeding effects on stored-product insects according to Geng et al. (2011).

Euphorbia bupleuroides latex was tested several times against common species and pest insects that are widespread in houses, restaurants, and food stockages (Saito and Hama, 2000). For example, It was proven effective and toxtic against Blattella germanica Linnaeus, 1767 adults and larvae (Azoui et al.,2016) .

Vimal and Das (2014) confirmed that mortality rates increased with the increase in concentration of $E u$ phorbia antiquorum L. latex extract. It was also found that latex was a strong pesticide against Aedes aegypti (Linnaeus and Hasselquist,1762) larvae, where $\mathrm{LC}_{50}$ val- 
ue was $14.34 \mathrm{ml} \mathrm{dl}^{-1}$ after 24 hours, $10.70 \mathrm{ml} \mathrm{dl}^{-1}$ after 48 hours, $6.62 \mathrm{ml} \mathrm{dl}^{-1}$ after 72 hours of exposure.

The insecticidal effects of Sebastiania corniculata Müll. against Laodelphax striatellus (Fallén,1826), Nilaparvata lugens ( Stål, 1854) and Sogatella furcifera (Horvath 1899), were evaluated by Lee et al. (2010). Results indicated that the chloroform fraction of $S$. corniculata possessed the highest potential for insecticidal activity against $L$. striatellus (DL50 $=1.09 \mu \mathrm{g} /$ female), $N$. lugens $(\mathrm{DL} 50=.46 \mu \mathrm{g} / \mathrm{female})$, and S. furcifera $(\mathrm{DL} 50=$ $2.32 \mu \mathrm{g} /$ female). (LD stands for "Lethal Dose". $\mathrm{LD}_{50}$ is the amount of a material, given all at once, which causes the death of $50 \%$ (one half) of a group of test insects).

Mwine et al. (2010) examined larvicidal properties of Euphorbia tirucalli L. latex against larvae of Anopheles mosquitoes. Results showed that the latex made total mortality at the highest dilution used of 1:250 in 5 days. Plant latex comprises of a substantial mixture of proteins and specialized products that include alkaloids, terpenoids, cardenolides, and many other components, most of which are toxic against insects and pathogens (Agrawal and Konno, 2009; Hua et al., 2015; Huber et al., 2015; Konno, 2011; Konno et al., 2006).

Numerous ingredients have been isolated from the extracts of Euphorbia species (Jain et al., 2008). Al-Younis and Abdullah (2009) identified flavonoids and phenolic acids from several species of Euphorbia genus including Euphorbia granulata Forssk. and Euphorbia heliscopia L. Different triterpenoids and diterpenoids were isolated from various Euphorbia species (Sutthivaiyakit et al., 2000; Sun et al., 2011; Aichour et al., 2014). According to Lima et al (2006), terpenoids are the most significant element in the insecticidal property of several plant species.

\section{CONCLUSION}

This study confirms the success of latex as a biopesticide against certain stored products insect species; namely, T. castaneum and T. granarium. Hence, latex could serve as an alternative to synthetic insecticides for the protection of stored grain. Further studies and investigations are necessary to isolate the active insecticidal compounds of the latex and study the insecticidal effects of these compounds.

\section{REFERENCES}

Abdel-Sattar, E., Zaitoun, A.A., Farag, M.A., Gayed, S. H. E., \& Harraz, F. M. H. (2010). Chemical composition, insecticidal and insect repellent activity of Schinus mole L. leaf and fruit essential oils against Trogoderma granarium and
Tribolium castaneum. Natural Product Research, 24(3), 226-235. https://doi.org/10.1080/14786410802346223

Agrawal, A.A., \& Konno, K. (2009). Latex: A Model for Understanding Mechanisms, Ecology, and Evolution of Plant Defense Against Herbivory. Annual Review of Ecology, Evolution, and Systematics, 40(1), 311-331. https://doi. org/10.1146/annurev.ecolsys.110308.120307

Aichour, S., Haba, H., Benkhaled, M., Harakat, D., Lavaud, C. (2014). Terpenoids and other constituents from Euphorbia bupleuroides. Photochemistry Letters, 10, 198-203. https:// doi.org/10.1016/j.phytol.2014.09.011

AL-Younis, N.K. and Abdullah, A.F. (2009). Isolation and antibacterial evaluation of plant extracts from some medicinal plants in Kurdistan region. J. Duhok University,12(1), 250255.

Aslanturk, O.S., C, elik, T.A.(2013). Antioxidant, cytotoxic and apoptotic activities of extracts from medicinal plant $\mathrm{Eu}$ phorbia platyphyllos L. Journal of Medicinal Plants Research, 7, 1293-1304. https://doi.org/10.5897/JMPR.12.608

Azoui, I., Frah, N., Nia, B. (2016). Insecticidal effect of Euphorbia bupleuroides latex on Blattella germanica (Dictyoptera: Blattellidae). International Journal of Pure and Applied Zoology, 4(3), 271-276.

Bohinc, T., Horvat, A., Ocvirk, M., Košir, I. J., Rutnik, K., \& Trdan, S. (2020). The first evidence of the insecticidal potential of plant powders from invasive alien plants against rice weevil under laboratory conditions. Applied Sciences, 10(21), 7828. https://doi.org/10.3390/app10217828

Cateni, F., Zilic, J., Zacchigna, M., Procida, G.( 2010). Cerebrosides with antiprolifera-tive activity from Euphorbia peplis L.. Fitoterapia, 81, 97-103. https://doi.org/10.1016/j. fitote.2009.08.022

Chang, K.S., and Anh, Y.J. (2002). Fumigant activity of (E)anethole identified in Illicium verum against Blatella germanica. Pest Management Science, 58, 161-166. https://doi. org/10.1002/ps.435

De Silva, W.A.P.P., Manuweera, G.K., Karunaratne, S.H.P.P. (2008). Insecticidal activity of Euphorbia antiquorum L. latex and its preliminary chemical analysis. Journal of the National Science Foundation of Sri Lanka, 36, 15-23. https:// doi.org/10.4038/jnsfsr.v36i1.129

Finney, D.J.(1971). Probit Analysis, Cambridge University Press, Cambridge, England, ISBN: 052108041X Wheeler, M.W.

Geng, Z. F., Liu, Z. L., Wang, C. F., Liu, Q. Z., Shem, S.M., Lin, Z.M., Du, S.S., Deng, Z.W.(2011). Feeding deterrents against two grain storage insects from Euphorbia fischeriana. Molecules, 16, 466-476. https://doi.org/10.3390/molecules 16010466

Giner, J.L., Berkowitz, J.D., Andersson, T.( 2000). Nonpolar components of the latex of Euphorbia peplus. Journal of Natural Products, 63, 267-269. https://doi.org/10.1021/ np990081g

Govindarajan, M., Jebanesan, A., Pushpanathan, T., \& Samidurai, K. (2008). Studies on effect of Acalypha indica L. (Euphorbiaceae) leaf extracts on the malarial vector, Anopheles stephensi Liston (Diptera:Culicidae). Parasitology Research, 103(3), 691-695. https://doi.org/10.1007/s00436-0081032-2

Hua, J., Liu, Y.-C., Jing, S.-X., Luo, S.-H., \& Li, S.-H. 
(2015). Macrocyclic diterpenoids from the latex of Euphorbia helioscopia. Natural Product Communications, 10(12), 1934578X1501001. https://doi. org/10.1177/1934578X1501001206

Huber, M., Triebwasser-Freese, D., Reichelt, M., Heiling, S. Paetz, C., Chandran, J. N., ... Erb, M. (2015). Identification, quantification, spatiotemporal distribution and genetic variation of major latex secondary metabolites in the common dandelion (Taraxacum officinale agg.). Phytochemistry, 115, 89-98. https://doi.org/10.1016/j.phytochem.2015.01.003

Isman, M. B. (2017). Bridging the gap: Moving botanical insecticides from the laboratory to the farm. Industrial Crops and Products, 110, 10-14. https://doi.org/10.1016/j.indcrop.2017.07.012

Jain, R., Jindal, C., Sing, S., Datta, A. (2008). Phormaceutical compositions comprising an extract of E. prostrata US patent/ patent no. US 7, 731,412 B2 May 13.

Konno, K., Ono, H., Nakamura, M., Tateishi, K., Hirayama, C., Tamura, Y., Kohno, K. (2006). Mulberry latex rich in antidiabetic sugar-mimic alkaloids forces dieting on caterpillars. Proceedings of the National Academy of Sciences, 103(5), 1337-1341. https://doi.org/10.1073/pnas.0506944103

Konno, K. (2011). Plant latex and other exudates as plant defense systems: Roles of various defense chemicals and proteins contained therein. Phytochemistry, 72(13), 1510-1530. https://doi.org/10.1016/j.phytochem.2011.02.016

Lee, C.H., Jeon, J., Lee, S. and Lee, H. (2010). Insecticidal properties of Euphorbiaceae: Sebastiania corniculata derived 8-hydroxyquinoline and its derivatives against three plant hopper species (Hemiptera: Delphacidae). Journal of the Korean Society for Applied Biological Chemistry, 53, 464469. https://doi.org/10.3839/jksabc.2010.071

Lima, M.G.A., Maia, I.C.C., Sousa, B.D., Morais, S.M., Freitas, S.M. (2006) . Effect of stalk and leaf extracts from Euphorbiaceae species on Aedes aegypti (Diptera : Culicidae) larvae.Revista do Instituto de Medicina Tropical de São Paulo, 48(4), 211-214. http://dx.doi.org/10.1590/S003646652006000400007.

Murugan, K., Kovendan, K., Vincent, S., \& Barnard, D. R. (2011). Biolarvicidal and pupicidal activity of Acalypha alnifolia Klein ex Willd. (Family: Euphorbiaceae) leaf extract and Microbial insecticide, Metarhizium anisopliae (Metsch.) against malaria fever mosquito, Anopheles stephensi Liston. (Diptera: Culicidae). Parasitology Research, 110(6), 2263-2270. https://doi.org/10.1007/s00436-0112758-9

Mwine, J., Damme, P. and Jumba, F., (2010). Evaluation of larvicidal properties of the latex of Euphorbia tirucalli L. (Euphorbiaceae) against larvae of Anopheles mosquitoes. Journal of Medicinal Plants Research, 4(19), 1954-1959. https:// doi.org/10.5897/JMPR10.383
Quezel, P., and Santa, S. (1963). Nouvelle Flore de l'Algérie et des régions désertiques méridionales, vol. 1-2. CNRS, Paris

Rafael, E. (2001). Botanical insecticides. www.ipmworld. umn. edu/silvia.html. Accessed on 12 October 2001.

Robertson, J.L., Savin, N.E., Russell, R.M. and Preisler, H.K. (2007). Bioassays with arthropods. CRC press. ISBN: $9780849323317 \mathrm{https} / / /$ doi.org/10.1201/9781420004045

Saito, T., and Hama, H .(2000). Carboxylesterase isozymes responsible for organophosphate resistance in the cotton aphid, Aphis gossypy Glover (Homoptera: Aphididae). Applied Entomology and Zoology, 35, 171-175. https://doi. org/10.1303/aez.2000.171

Salvadores U, Y., Silva A, G., Tapia V, M., \& Hepp G, R. (2007). Polvos de especias aromáticas para el control del gorgojo del maiz, Sitophilus zeamais Motschulsky, en trigo almacenado. Agricultura Técnica, 67(2). https://doi.org/10.4067/ S0365-28072007000200004

Singh, P., and Singh, A. (2012). Evaluation of latex extract of Euphorbia royleana for its piscicidal and muricidal activities. World Journal of Agricultural Sciences, 8(5), 520-524.

Sun, Y.-X., \& Liu, J.-C. (2011). Chemical constituents and biological activities of Euphorbia fischeriana Steud. Chemistry \& Biodiversity, 8(7), 1205-1214. https://doi.org/10.1002/ cbdv.201000115

Sutthivaiyakit, S., Thapsut, M., \& Prachayasittikul, V. (2000). Constituents and bioactivity of the tubers of Euphorbia sessiliflora. Phytochemistry, 53(8), 947-950. https://doi. org/10.1016/S0031-9422(99)00606-8

Tanaka, R., Kasubuchi, K., Kita, S., Tokuda, H., Nishino, H., \& Matsunaga, S. (2000). Bioactive Steroids from the Whole Herb of Euphorbia chamaesyce. Journal of Natural Products, 63(1), 99-103. https://doi.org/10.1021/np990394b

Vasas, A., Sulyok, E., Martins, A., Redei, D., Forgo, P., Kele, Z., Zupko, I., Molnar, J., Pinke, G.,

Hohmann, J. (2012). Cyclomyrsinane and premyrsinane diterpenes from Euphorbia falcata modulate resistance of cancer cells to doxorubicin. Tetrahedron, 68, 1280-1285. https:// doi.org/10.1016/j.tet.2011.11.039

Vimal, J.B., and Das, S.S.M.(2014). Euphorbia antiquorum latex and its mosquitocidal potency against Aedes aegypti. Journal of Entomology and Zoology Studies, 2(6), 267-269.

Webster, G.L., (1994). Classification of the Euphorbiaceae. Annals of the Missouri Botanical Garden, 81(1), 3-32. https://doi. org/10.2307/2399908

Wink, M. (1993). Production and application of phytochemicals from an agricultural perspective. In: van Beek TA, Breteler H, editors. Phytochemistry and Agriculture. Oxford, UK: Clarendon Press 34: pp. 171-213.Top of Form Bottom of Form 